\title{
Cyber-addiction psychoprophylaxis program for young generation of Ukraine
}

\section{Програма психопрофілактики кіберзалежності для молодого покоління України}

Received: March 4, 2021

Accepted: April 30, 2021

\author{
Written by: \\ Yuliia Asieieva $^{3}$ \\ https://orcid.org/0000-0003-3086-3993 \\ Oleg Druz ${ }^{4}$ \\ https://orcid.org/0000-0002-5149-9556 \\ Hanna Kozhyna ${ }^{5}$ \\ https://orcid.org/0000-0002-2000-707X \\ Inna Chernenko 6 \\ https://orcid.org/0000-0003-3584-736X
}

\begin{abstract}
In the work the authors provides a statistical analysis of the problem, considers possible measures for the prevention and correction of cyber addictions among the younger generation. Proposed: a scheme of interaction in the formation of media culture; a preventive cyber addiction prophylaxis scheme; a number of practical recommendations on the peculiarities of socialization of adolescents with cyber-addiction are described; the basic principles of working with cyber-addicts are highlighted. It is emphasized that the ways of overcoming cyberaddictions should have a socio-psychological direction aimed at: correction of behavioral deficiencies; changing the life program so that a person has the opportunity to satisfy his needs focusing not on the virtual environment, but on the surrounding reality; developing the ability to establish constructive relationships with people around; displacing being in cyberspace from leading activities; normalization of emotional response to difficult life situations.
\end{abstract}

Keywords: cyber socialization, cyberspace, adolescents, adolescence, psychocorrection.

\begin{abstract}
Анотація
У роботі автори проводять статистичний аналіз проблеми, розглядають можливі заходи щодо профілактики та корекції кібер-адикцій серед молодого покоління. Запропоновано: схему взаємодії при формуванні медіа-культури; схему превентивної профілактики кіберадикцій; описано низку практичних рекомендацій 3 питань особливостей соціалізації підлітків, захоплених кіберпростором; відокремлено основні принципи роботи із кібер-адиктами. Підкреслено, що шляхи подолання кіберадикцій повинні мати соціально-психологічний напрямок спрямований на: корекцію недоліків поведінки; зміну життєвої програми, щоб особистість отримала змогу задовольняти свої потреби орієнтуючись не на віртуальне середовище, а на оточуючу дійсність; розвиток здатності до встановлення конструктивних стосунків з оточуючими людьми; витіснення перебування у кіберпросторі з провідних видів діяльності; нормалізацію емоційного реагування на складні життєві ситуації.
\end{abstract}

$\begin{array}{lll}\text { Ключові } & \text { слова: } & \text { кібер-соціалізація, } \\ \text { кіберпростір, } & \text { підлітки, } & \text { підлітковий } \\ \text { психокорекція. } & & \end{array}$

\footnotetext{
${ }^{3} \mathrm{PhD}$, Head of the Department of General Scientific, Social and Behavioral Disciplines of the Odessa Institute of the Interregional Academy of Personnel Management, Ukraine.

${ }^{4}$ Doctor of Medical Sciences, Head psychiatrist of Ministry of Defense of Ukraine, colonel of medical service, Head of the Psychiatric Clinic (with rooms for drug addicted) of National Military Medical Clinical Centre "Main Military Clinical Hospital" of the Ministry of Defense of Ukraine, Ukraine.

${ }^{5}$ Professor, Academician of the National Academy of Higher Education of Ukraine, PhD, MSc, MD Head of Department of Psychiatry, Narcology, Medical Psychology and Social Work of Kharkiv National Medical UniversityUkraine, Ukraine.

${ }^{6} \mathrm{PhD}$, doctor of the Psychiatric Clinic (with rooms for drug-addicted) of National Military Medical Clinical Centre "Main Military Clinical Hospital"of the Ministry of Defense of Ukraine, Major of medical service, Ukraine.
} 


\section{Introduction}

The active formation of the modern young generation, its mobility, curiosity and activity motivate society to create conditions for freer access to the World Wide Web, and this, in turn, leads to the formation of cyber-addictions of the individual. Also, the emergence of this phenomenon can be influenced by various other negative factors, in particular: intolerance, alienation, loneliness, they are what make people look for an alternative, comfortable, virtual reality. This allows you to escape or hide from important difficulties, but not solve them. Given this, it is especially important to consider possible ways to overcome cyber-addictions by means of psychoprophylaxis and psychocorrection.

In a world where, as a result of technology development, we have learned to communicate with the help of «smilies» and messages consisting of less than 280 characters, it is becoming increasingly difficult to develop communication skills. And it is very difficult to identify situations in which these skills are used against us. In addition, thanks to social networks, our society has changed: it has become normal and even encourages to tell about themselves absolutely everything to everyone.

A study by In Mind Factum Group shows that 12,9 million Ukrainians (33\%) use the Internet once a month and more often, 11,8 million $(30 \%)$ - once a week and more often, 8,7 million (22\%) - daily or almost daily. The socio-demographic structure of Internet users is as follows - among Internet users men (54\%) dominate, by age criteria $58 \%$ are taken by adolescents and young people aged 15 - 30 years, $29 \%$ - users aged 31 - 45 years, and $13 \%$ - people aged 46 and over. By type of settlement, $58 \%$ of network users live in cities with a population of more than 100 thousand people, $25 \%$ - under 100 thousand, and the rest $13 \%$ - in villages (Bartkiv, \& Makhnovets, 2018; Rzhevsky, 2018; Griffiths, Kuss, \& Billieux, 2019; Zhaojun, Pontesbc, \& Guangcan, 2020).

A study by the National Academy of Legal Sciences of Ukraine, conducted in 2018, indicates that today $14-16 \%$ of children in Ukraine suffer from cyber-addiction. $6-8 \%$ of adolescents have psychological diseases: schizophrenia, neuralgia, musculoskeletal disorders (scoliosis, osteochondrosis, osteoarthritis), myopia. On the average, students spend 5-6 hours a day online, but this is not the limit and some are online for up to 16 hours
(Polyakova, 2018; Zhaojun, Pontesbc, \& Guangcan, 2020; Kemp, 2020).

In December 2017, the World Health Organization (WHO) officially announced the inclusion of video game addiction in the International Classification of Diseases (ICD). The disease was given the term «gaming disorder». Among the symptoms of the new disease there are loss of control over the time and frequency of the gameplay, high priority of the game over the life interests, and the continuation of the game despite the negative consequences. It is possible that sooner or later the ICD will include cyber-addictions. Moreover, the recognition of addictions to «selfies», social networks and the Internet in general as mental disorders were discussed by experts from the WHO two years ago (Rumpf, Achab, \& Billieux, 2018; WHO, 2017)

Today there are no statistics on the problem of cyber-addictions in Ukraine, as this type of addiction is not allocated to a separate nosological form, users of Internet, PCs, gadgets and other electronic devices are considered addicted from $2 \%$ to $6 \%$, the vast majority of which - students. In the group of adolescents with a high level of cyber-addiction, the quotient of males is almost a third higher than the quotient of females. Almost the same indicators were found by experts, who established that every fifteenth person $(6,54 \%)$ who has experience of working on the Internet, becomes addicted to it in adolescence (Borisova, \& Soltan, 2019; Fomenko, \& Semenczova, 2018; Khilko, 2018; Markova, 2013; Aymedov, Asieieva, \& Cherevko, 2017).

The purpose is to analyse modern research on the psychoprophylaxis and psychocorrection of cyber-addictions and to develop a program of psycho-prevention of cyber-addictions among the younger generation.

\section{Objectives}

1. To study the degree of development of the problem of cyber-addictions in modern scientific-practical and theoreticalmethodological sources.

2. To observe the existing programs of prevention and psychocorrection of cyberaddictions.

3. To develop own concept for the prevention of cyber-addictions among the younger generation of Ukrainians. 


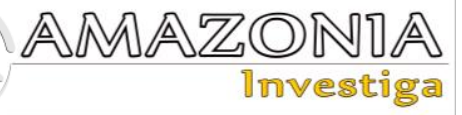

\section{Research methods}

The theoretical method included theoreticalmethodological analysis, generalization of social, psychological, medical achievements on the topic of research, it was also organized the systematization of existing modern literary sources on the prevalence of cyber-addiction and existing prevention approaches among the younger generation of Ukrainians.

Analysis and generalization of sociopsychological, medical-psychological, psychological and educational literature was aimed at reflecting the current state of the problem of cyber-addiction and creating its own conceptual prevention program.

\section{Analysis of recent research and publications.}

Cyberspace dependency is now seen as a multidisciplinary issue in three main directions: psychological, social and medical. From a social perspective, cyberspace is seen as a type of deviation (Berezhnova, \& Moskalenko, 2017; Young, 1996; Soldatova, \& Rasskazova 2017; Sherbakova, 2018). The views of medical and psychological experts have recently come down to a position that the cyber-addiction is a pathological attraction or disease which is classified as non-chemical addiction and has its own nosology, etiology, pathogenesis and requires prevention, treatment and psychocorrection. (Aymedov, Asieieva, \& Cherevko, 2017; Bolbot, 2005; Jeong et. al. 2020; Molyako, 2013; Naydionova, 2017; Otte, Streb, Rasche, \& Franke, 2019; Utz, 2015; Blachnio, Przepiorka, Benvenuti, Mazzoni, \& Gwendolyn, 2019).

\section{Results}

Despite the scientific developments in the field of analysis of the situation of the prevalence of cyber-addictions in Ukraine in comparison to addictions of other origins (alcoholism, drug addiction, pathological gambling, etc.), this problem is insufficiently studied, and patterns of formation, causes and conditions, diagnostic criteria and stages are little explored. Issues of methods of treatment, means of correction and prevention of this disorder remain underexplored. However, some isolated studies to identify diagnostic signs of cyber-addiction and the lack of accurate statistics indicate a deficient level of research base on this topic. It should also be emphasized that there is a lack of awareness on the subject of cyber-addictions among the majority of Internet users in Ukraine as well as a low level of parental attention to the use of the network by their children.

According to the results of the Internet risks for Ukrainian children and their parents research conducted by the Institute of Sociology of the National Academy of Sciences of Ukraine, it is possible to state the low level of informing the population about the rules of safe use of the Internet. Of particular note, in our opinion, is the fact that during the study there was a significant discrepancy between children's confidence in their awareness and the real level of being informed, which leads to a very risky behavior of children on the Internet.

Therefore, today society in general and professionals in this field need to unite their efforts and take the necessary measures to protect all users from the dangers of cyberspace and teach them the rules of secure indirect work with information and communication technologies (ICT) and cyberspace.

The Internet Research Institute provides the following data: $23 \%$ of parents use any means of online security, except for antivirus. Over the last three years, the number of families using Safe (Child) Search settings has increased from 5\% to $23 \%$. The popularity of the «Children's Internet» service from the provider has tripled. The reason for these changes is that more attention has been paid to information security, and «advanced» young parents have appeared (Zhaojun, Pontesbc, \& Guangcan, 2020).

It is possible to establish the following list of advice to parents at the first acquaintance of the child with cyberspace:

1. Limit the time spent in the network.

2. It is necessary to use security (anti-virus program, safe search settings, safe mode in social networks, use thematic filters).

3. Connect the «Children's Internet» service from the provider.

4. «Parental control». You can use this feature in Windows OS to control the use of the computer by children.

5. Install the free program «Internet Censor». It blocks sites that parents do not want their children to access from their computers.

6. Make sure that the child watches ageappropriate programs / movies $(0+, 6+, 12+$, $16+, 18+)$.

7. Explain to children that not everything written on the Internet is true. Explain the dangers of the «World Wide Web». 
8. Inform the child that $s$ he doesn't have to indicate her/his real name somewhere during registration. It is necessary to help the young user to choose a reliable login.

9. Monitor the child's friends and subscribers on social networks (whether there are adults, strangers from another school / city / district).

10. Explain that online friends may be different when meeting in real life. And let online friendship remain so (at least for younger students).

11. Be attentive to the child. Make sure $s / h e$ is not a victim of Internet bullying. If the child does not have friends in the subscriptions, it is possible that $\mathrm{s} / \mathrm{he}$ deleted them precisely because $\mathrm{s} / \mathrm{he}$ was bullied by them.

12. Listen and support the child in any situation. Spend more time together. Try to read together and reflect on what you have read. Prefer active games than being in four walls.

13. Explain that $\mathrm{s} /$ he doesn't have to download files from strangers.

14. Computer games should be introduced only after the formation of gaming and creative activities, i.e. after 6 years. By this time, the baby can do without the virtual world.

15. Remember that a child up to 6-7 years does not need the Internet. 30 minutes a day is enough for younger students, according to pediatricians. At the age of $10-12$, a child has to spend no more than 1 hour on the Internet. Older than 12 - no more than 1,5 hours.

16. In addition, parents should also use their social networks with caution. Very often adults post photos and videos of their children into their account. Everyone has their own goals: someone wants to share photos of their babies with online friends, someone uses them to promote their profile (e.g. bloggers). In any case, this is a large information base for fraudsters (Soldatova, \& Rasskazova, 2017; Sherbakova, 2018; Boram, \& Yoon, 2020; Fomenko, \& Semenczova, 2018).

It should be noted that at the same time in Ukraine there is a tendency to gradual increase of the attention of representatives of research organizations, private entities and public authorities to this issue. In particular, it is worth noting the implemented initiatives of the Ministry of Education and Science of Ukraine in the framework of informational and educational work on safe usage of the Internet. Regarding practical steps in the field of prevention of cyberaddictions, it should be noted that the Ministry cooperates with government, business structures, non-governmental organizations in order to address these issues. The study of the topic of safe work on the Internet is provided by the current programs of school courses «Computer Science» and «Fundamentals of Health», namely:

- school curriculum for computer studies for 9-12 grades of secondary schools. Academic level (authors: Zavadsky, Potapova, \& Doroshenko, 2008);

- school curriculum for computer studies for 9-12 grades of secondary schools. Standard level (authors: Zavadsky, Potapova, \& Doroshenko, 2008);

- curriculum for computer studies for a night secondary school (authors: Litvinova, \& Protsenko, 2006);

- curriculum on the «Fundamentals of Health» subject for 5-9 grades of secondary schools (Order № 664, 2012).

Since 2009, the Ministry has been a member of the All-Ukrainian Coalition for the Safety of Children on the Internet and supports its initiatives, conducts informational and educational activities (educational and practical conferences, Safe Internet Days, etc.) aimed at overcoming the problem of cyber-addiction due to the program called «On-land - Child Safety on the Internet». The Coalition for the Safety of Children on the Internet was established in 2008 at the initiative of Microsoft Ukraine.

The first step of the coalition was the launch in April 2008 of the «On-Land - Safe Web Country» website, which provides materials for children, their parents and teachers to help them learn the basics of safe online work on the Internet.

In this regard, in February 2010, the Ministry of Education and Science recommended Ukrainian schools to hold informational events for children and parents on the occasion of Safer Internet Day, dedicated to online family safety. Accordingly, many educational institutions held competitions, open lessons, quizzes, parent meetings, during which participants learned the rules of safe use of the Internet. On February 9, 2010, the Coalition for the Safety of Children on the Internet held an educational conference dedicated to the European Safer Internet Day, which is celebrated in more than 50 countries on the first Tuesday in February. And if earlier the main purpose of such events was to draw the attention of the public and government institutions to the problem of child protection in the global information space, now the organizers 


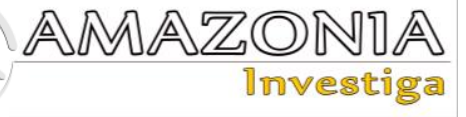

addressed directly to parents. It is the parents who are primarily responsible for the safety of children, which is why they must raise the level of media culture, both their own and their children's.

Deployment of work on prevention and overcoming of cyber-addictions requires first of all creation of the corresponding legislative and normative base. To do this, according to experts from the Institute of Social and Political Psychology, it is necessary to appropriately modernize existing legislation related to this problem, to supplement the current legislation with new legislative acts. In particular, it is necessary to develop and adopt the Law of Ukraine «On Protection of Mental Health», which has long been necessary to do in accordance with the requirements of the WHO and the World Medical Association. It is also necessary to amend the Standard Regulation on the Centre for Social and Psychological Assistance (Resolution № 60-8, 2004), entrusting such centers with the implementation of measures to prevent Internet addiction and collective work with cyber addicts.

Following proposals are offered

1) given that the use of the Internet and other telecommunications technologies is associated not only with the user in an artificial electromagnetic field, but also the risk of addiction, the program «Health of the Nation» and other government programs should provide systematic and comprehensive research on the impact of these technologies on physical and mental health with the participation of leading scientific institutions in the country (including the Institute of Neurology, Psychiatry and Addiction of the National Academy of Medical Sciences of Ukraine). According to the results of these studies, the existing age hygiene standards for the use of ICT should be revised to take into account the risk of addiction to them;

2) materials on safe use of the Internet and other ICTs should be included in the school course of computer science, as well as in lesson plans with students' parents, with the obligatory presentation of the first signs of the formation of the corresponding dependence.

However, it should be borne in mind that the problem of cyber-addictions can not be effectively solved in isolation from other problems of personality formation and functioning in the modern information society. This requires the organization of an extensive system of media education of the population and especially young people (Bolbot, 2005; Naydionova, 2017; Rumpf, Achab, \& Billieux, 2018; Sherbakova, 2018).

It should be noted that the concept of media education has not yet been developed in Ukraine. Its main goal should be to promote the widespread development of an effective media education system to ensure comprehensive preparation of children and youth for safe and effective interaction with the modern cyberspace system, formation a media culture in them in accordance with their age and individual characteristics. Currently, work is underway to organize an all-Ukrainian experiment on the introduction of media education in secondary schools. In the future, the development of curricula and the organization of an experiment on the training of media teachers and media psychologists on the basis of higher primary schools and institutions of postgraduate pedagogical education are foreseen. According to experts of the Institute of Social and Political Psychology of the National Academy of Pedagogical Sciences of Ukraine, after the completion of experimental work and public discussion of their results, it is advisable to develop and adopt a State program for implementing media education in Ukraine (Ilnytska, 2012; Molyako, 2013).

Based on the above, a number of practical recommendations were developed on the specifics of socialization of adolescents fascinated by cyberspace, which are presented and substantiated below.

1. Cyber addict cannot be isolated from society. Here the concepts of rehabilitation and socialization are intertwined. Adolescents must learn to resist the temptation to spend time in cyberspace, with the help of a social environment, and not just with the intervention of individual professionals. This statement explains another principle of socialization of adolescents with a certain type of cyberaddiction. The process of adolescent communication with cyberspace should take place without separation from the learning process and under the guidance and supervision of adults.

2. Psycho-correctional work with cyberaddicts should take place in the places of direct life of adolescents (schools, colleges, vocational schools, free educational 
institutions, etc.), which will promote their socialization, rather than resocialization and deepening of the problem. Because the fundamental acquisition of adolescence is socialization and finding one's place in important social groups. It is not desirable to apply treatment to addicted adolescents in a separate rehabilitation institution, because it can lead to trauma to the still undeveloped child, adolescent psyche. Being indoors, even for a short time, leads for teenagers to stigmatization by peers.

3. The socialization of adolescents who have certain types of cyber-addictions should take place with the constant participation and support of peers who do not have such addiction. Of course, it is important to receive support from teachers, psychologists and other professionals, but their role is more to guide adolescents in the right direction, curation during mass events (trips to nature, the organization of training). Adolescents have a very strong influence on each other's thoughts. Only friends can «distract» a teenager from a computer monitor by offering to go for a walk or, for example, play football, where you also feel the excitement of the game.

4. Given the newness of the problem of cyberaddictions in Ukraine, it is necessary to intensify the information campaign on the prevention of this disease among the general population. This is especially true for the younger generation and parents. In order to implement this initiative, the state should more actively involve private structures, non-governmental organizations and scientific institutions. One of the steps in this direction could be holding public discussions on the threat of cyber addiction. The Ministry of Health and the Academy of Medical Sciences of Ukraine should consider conducting systematic research on the problem of cyber-addictions and develop specific recommendations for the prevention and treatment of this form of addiction.
These studies can be carried out on the basis of subordinate organizations, which are part of the structure of the Ministry and the Academy of Medical Sciences of Ukraine.

5. It is expedient to establish a system of online consultations on the problem of cyberaddictions in order to provide prompt consultations to the addicts themselves and their relatives.

Based on the developed recommendations, we can assume in the future the possibility of creating a separate program for the socialization of adolescents with cyber-addiction. It will take into account the features of this type of addiction, as well as the features and needs of the target audience (adolescents themselves). In this case, it is still difficult to talk about the development of a specific program, due to the lack of comprehensive research in this area. Before developing the program itself, the features of the «portrait» of a cyber-addict, determinants of formation and contributing factors were studied and described, methods for identifying various types of cyber-addiction, etc. were developed, the results of these studies served as a basis for the formation of the basic principles of socialization of adolescents.

Work on the prevention of cyber-addictions should take place both at the state level, where programs are developed to prevent the formation of addiction, in particular among young people, and at the level of individual researchers who offer author's programs. We should not forget about public charitable organizations, international projects and grants for the prevention of cyber-addictions, in which Ukrainians can be involved. Public prevention of cyber-addictions may include social, educational activities conducted by social workers in cooperation with government institutions and NGOs to study the impact of the Internet on various spheres of life and comprehensively inform citizens about the risks of cyberspace, information culture education (pic. 1) 


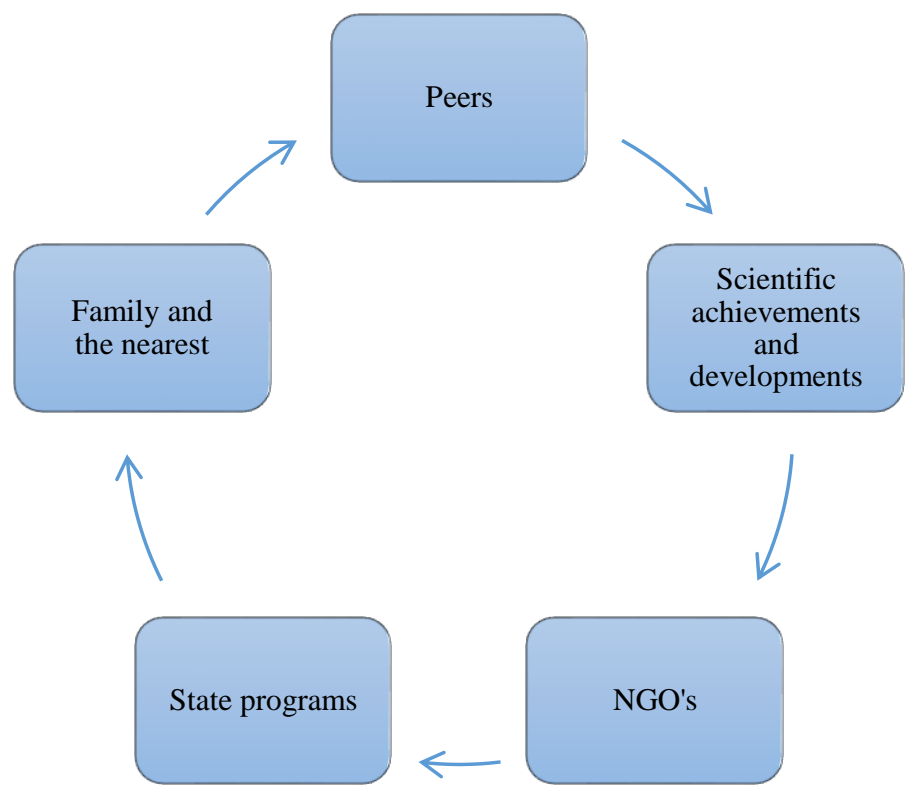

Pic. 1. Scheme of interaction in the formation of media culture (own authorship)

In our opinion, the formation of media culture in the current environment is possible with the fruitful cooperation of scientists, the implementation of their programs at the state level with the involvement of NGOs and communication to parents and the organization of interaction of information transfer on a peerto-peer basis. Proper and comprehensive involvement of the younger generation in the process of informing and implementing prevention facilities to prevent the spread of cyber-addictions will positively contribute to informational and educational work on this issue.

It should be noted that based on the Concept of preventive education of children and youth of Ukraine, approved by the Presidium of the Academy of Pedagogical Sciences of Ukraine on 25.02.98 (Protocol № 1-7 / 3-21) which reveals the theoretical and methodological principles of prevention, which is divided into primary, secondary and tertiary prevention, it is possible to build a concept of comprehensive prevention of cyber-addictions among the younger generation. Based on the interpretation of this concept as a working concept under the prevention of deviant behavior of adolescents we understand the process aimed at implementing a set of educational and preventive measures to influence the personality of adolescents to prevent various types of deviant behavior in the early stages of deviation, as well as actions to implement psychological-pedagogical and sociotherapeutic impact on the individual.
Preventive prophylactic measures of cyberaddictions should be based on the following principles:

- the principle of complexity - the implementation of prophylactic measures to prevent cyber-addictions among the younger generation should involve both government agencies and NGOs, as well as training activities in which addicts are trained. We should not forget about parents and peers, which can have a positive effect on addicts in the course of their daily lives;

- the principle of systematization - provides not only the consistency of all participants in preventive work, but also their constant interaction and systematic work with the younger generation, supporting young people in organizing prevention activities and informational and educational work;

- $\quad$ the principle of scientificity - programs and activities should be based on modern research of scientists from different fields of science and the introduction of new methods and techniques for their implementation;

- the principle of integration - ensures the implementation of world experience, taking into account our socio-cultural characteristics;

- the principle of mobility - provides an opportunity to quickly and effectively modify the developed programs to the rapidly changing conditions of modernity and development of ICT;

- the principle of continuity - allows you to modify programs based on previous 
experience, based on an analysis of the effectiveness of already implemented programs;

- the principle of realism - provides optimization of forms and methods of implementation of prevention programs in inseparability from the material reality directly among the selected target audience aimed at adapting the younger generation in a changing social environment with minimal use of cyberspace;

- the principle of ethics - ensures the confidentiality, respect and humane nature of prevention programs.

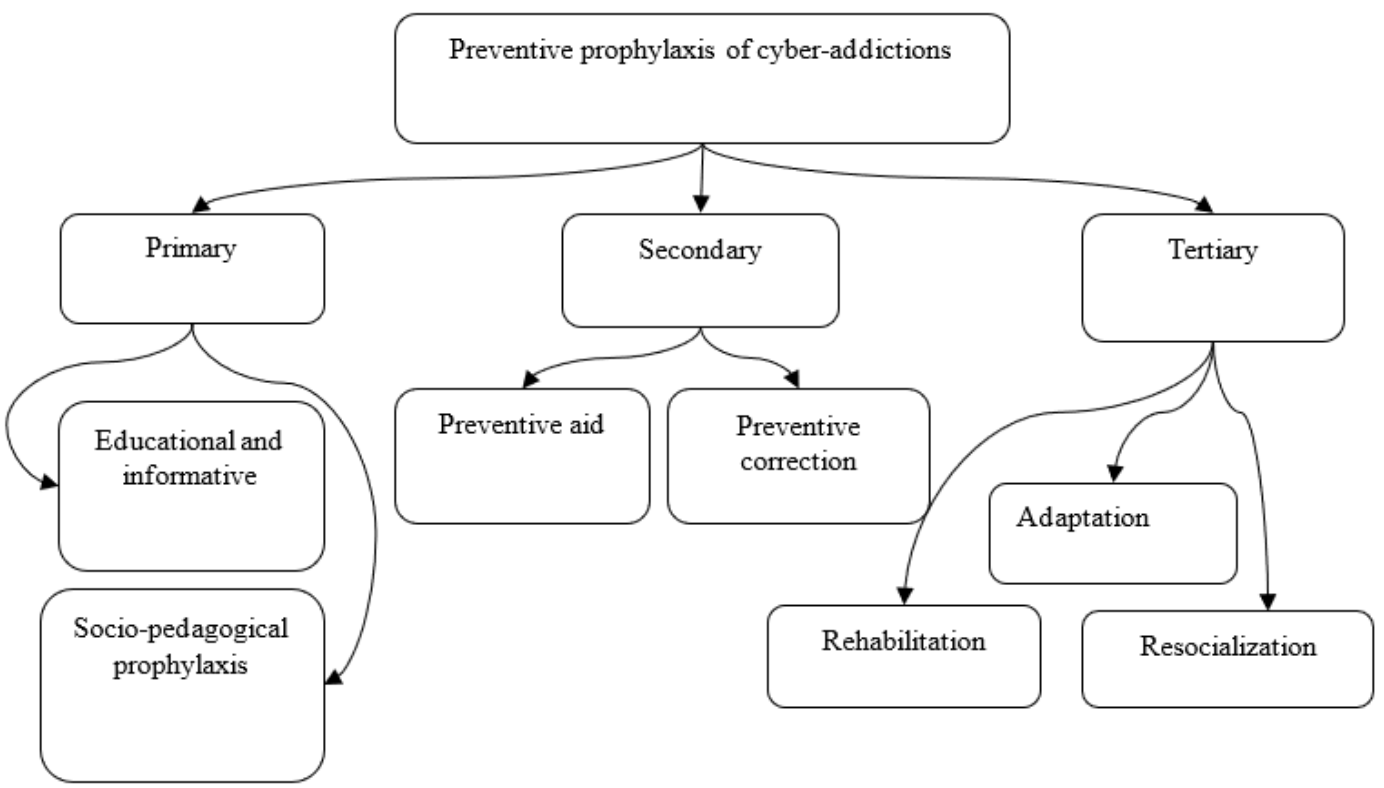

Pic. 2. Scheme of preventive prophylactic of cyber-addictions (own authorship)

On the basis of separate principles of prophylactic work on prevention of cyberaddictions (pic. 2) it is possible to distinguish its following stages: primary, secondary and tertiary.

Primary preventive prophylaxis should include a system of educational and informative measures to prevent the occurrence and impact of risk factors for the development of cyber-addictions. Activities should be carried out both at the interpersonal level and at the state level, be aimed at at-risk groups and the general public in order to inform about the causes, manifestations, consequences of cyber-addictive behavior.

Primary socio-pedagogical prevention is aimed at implementing a system of educational and prophylactic measures to prevent the emergence of various types of dangerous behavior in the early stages of deviation. The purpose of which is to timely identify and correct unfavorable informational, pedagogical, psychological, organizational and other factors that cause deviations in the socio-psychological development of children and youth, their behavior, health.
Modern researchers dealing with prevention issues emphasize that primary prophylaxis focuses its efforts on preserving and developing conditions that should contribute to the preservation of the life of the younger generation, and to prevent the negative impact on it of the social and natural environment. Prophylaxis should be based on a system of measures to prevent the occurrence and impact of risk factors for the development of cyber addictions. This system of measures should be implemented at the interpersonal level, at the state level and target risk groups and the general public in order to inform about the causes, manifestations, stages, types and consequences of cyber-addictions.

It should be noted that the prevention of addictive behavior should be carried out in all spheres of adolescent life: family, educational environment, social life. Mandatory components of primary prophylaxis are diagnostics, which includes the study of personal characteristics of the individual that may affect the formation of cyber-addiction (increased anxiety, inability to empathize, alexithymia, low stress resistance, unstable «selfconcept», hyper shyness, increased egocentrism, low perception of social support, avoidance strategy in overcoming stressful situations 


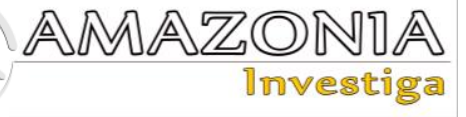

burdening heredity, organic brain damage, anosognosia, the degree of initial tolerance, temperament, genetic predisposition to addictions, disharmonious functioning of the emotional sphere, affective disorders; addictive craving; impaired ability to reflection; impaired self-esteem; psychological isolation; psychological immaturity, etc.), as well as obtaining information about the composition of the family and relationships in it, the system of relationships, whether there is disorganization in the micro-social environment. Special attention should be paid to determining the interests and abilities of the adolescent, information about his friends and other possible reference groups of the adolescent.

The informational and educational component of preventive prophylaxis of cyber-addictions is the expansion of adolescents' competencies in psychosexual development, culture of interpersonal relationships, communication technologies, ways to overcome stressful situations, conflictology and problems with cyber-addiction and its consequences.

Considering the substantive aspects of the primary prevention process, it should be emphasized that on the one hand, it is informing the individual about the positive aspects and dangers of cyberspace, signs of addictive behavior, and on the other - recommendations for «healthy use of cyberspace».

From the researches on this problem, it is possible to note that high self-control and involvement of addicts in various types of social activity: labor, cognitive-creative, political, social, etc., prevent cyber-addictions from developing. Therefore, primary prevention aims to inform young people about the impact mechanisms of the Internet on the individual, the causes, clinical manifestations, diagnostic methods and consequences of cyberspace addiction; formation of adolescents' strategies of highly functional behavior and a system of values appropriate to a healthy lifestyle; development of resistance to negative social influences and personal resources and skills to achieve goals in real life; expanding the range of alternative activities to the addictive one.

Primary prophylaxis is characterized by the following methods: video lectures, forums, conferences, online conferences, methodological seminars, round tables, discussions, promotions, competitions, etc. Primary prophylaxis is usually implemented at the individual, interpersonal and social levels with the assistance of the state.
Secondary prophylaxis (preventive aid and correction) in the Concept of preventive education of children and youth is considered as a type of psychological, pedagogical and medical and social activities, which consist in helping certain categories - «risk groups» and provide psychological, pedagogical and sociotherapeutic effects on the individual so that $\mathrm{s} / \mathrm{he}$ learns to help herself/himself by solving numerous problems that provoke destructive behavior.

According to research, secondary (early) prophylaxis is an activity to prevent possible violations of social mechanisms of moral regulation, according to which the system of measures is aimed at dealing with the consequences and eliminating risk factors, mainly at the individual and interpersonal levels. The task of secondary (early) prophylaxis of cyber-addictions, is seen by scientists in the earliest possible detection of negative changes in personality behavior.

Secondary prophylaxis (preventive aid and correction) is a system of measures aimed at dealing with the consequences and elimination of risk factors, mainly at the individual and interpersonal level (psychological counseling, therapy, assistance in socio-psychological adaptation, etc.). It should also be based on the results of the diagnosis of various aspects of adolescent life and serve as an individual plan of correctional work on the life of the adolescent. This activity should prevent further possible occurrence of various disorders in the behavior of the adolescent. It should be noted that solving the problem of successful prevention of adolescents' addiction on cyberspace should pay attention to the nature of the impact of cyberspace on the mental and physical characteristics of the adolescent, and the consequences that may be shifted in one direction or another depending on external (social) and internal (mental) factors, as well as the socializing and educational capabilities of computer resources, based on the personal characteristics of the adolescent.

Most often, an indicator of the necessary start of preventive measures is the nature of adolescent behavior that harms society or the interests of individuals, and which demonstrate aggression, rudeness, lying, negativism and other manifestations that indicate a distortion of value orientations and shortcomings of internal regulators of behavior (consciousness, sense of will, motives). 
We note that in studying the problem of prevention of cyber-addictions among adolescents, it is advisable to understand the essence of prevention not only in carrying out certain corrective measures aimed at identifying and eliminating its causes and conditions, but also the implementation of a system of social and educational work to form positive personality traits. That is, the importance of prevention, especially early, is enhanced by its humanistic orientation in the system of measures and means of social and educational work to prevent addiction.

The most common methods of secondary prophylaxis are psychological and pedagogical consultations, art therapy, assistance in sociopsychological adaptation, individual and group conversations, social and educational activities, socio-pedagogical training, the method of «peerto-peer» and others.

Tertiary prophylaxis is related to the processes of adaptation, rehabilitation and resocialization and is aimed at the reconstruction of the sociocultural environment for different categories of clients, assistance in communication, training to restore social ties or adaptation in social life.

Tertiary, or targeted prevention of cyberaddictions should include a set of measures aimed at preventing the transition of manifestations of superficial addiction to a more severe stage. Such prevention is most often focused on individual work with clients, partly group (peer-to-peer method, socio-pedagogical training, individual consultations, methods of prohibitions and punishments, etc.). Such work includes measures to identify and address specific shortcomings of family, school and social education, as well as the localization of a group of adolescents, and the excessive amount of time spent online. It should be noted that when the first and subsequent stages of cyberaddictions are detected, we move to the level of psychocorrection and treatment. However, as mentioned above, in our opinion, the process of psycho-correctional work with addicts should take place without separation from their normal life process from which they fell into cyberspace. And during tertiary prophylaxis, the understanding of the resocialization process changes somewhat. In the case of cyberaddictions, resocialization is understood as a return from cyberspace to the normal process of life (return to study, sports, music, walks, etc.) to a real round of friends and peers. Of particular importance is the adaptation of cyber-addiction, because, as we have noted, maladaptive constructs of behavior and some individual psychological characteristics of addicts are the reason for the formation of cyber-addiction. Therefore, in tertiary prophylaxis, the acquisition of adaptive skills to the real social environment becomes especially important, and sometimes requires the involvement of specialists.

\section{Conclusions}

In general, the means of psychoprophylaxis of cyber-addictions can be divided into informational (talks, lectures, seminars, workshops, round tables, conferences, consultations) and developmental (group discussion, art therapy, role play, psychodrama, methods of nonverbal interaction, training, busyness technologies). As an effective form of psychoprophylaxis of addiction, remote counselling can be used, which allows to provide the necessary psychological assistance without the need for direct contact with a psychologist, as it often causes resistance and anxiety in the individual.

It is also worth noting that in order for this work to be effective, it must affect all spheres of personal life: family, educational environment, social life. Data on which form of psychocorrectional work is more effective in providing assistance to cyber-addicts is contradictory. Thus, the expediency of conducting individual counselling and individual form of the method of symbol drama, REBT, ACT and group psychotherapeutic methods, group form of transactional analysis, psycho-correctional training programs for both peer groups and family psychotherapy is emphasized (Ilnytska, 2012; Naydionova, 2017; Fomenko, \& Semenczova, 2018; Borisova, \& Soltan, 2019).

The main means of psychocorrection of cyberaddicts include: psychological support; training (plasticity, positive learning, education and development in the context of life prospects of the individual: association, tolerance and stress resistance, the formation of rational attitudes, etc.) socio-psychological; transactional analysis (development of the ego-state of the «Adult»); symbol drama; music therapy, art therapy, REBT, ACT, etc.

In general, ways to overcome cyber-addictions should have a socio-psychological direction aimed at: correction of behavioral deficiencies; changing the life program so that the individual is able to meet their needs focusing not on the virtual environment, but on the surrounding reality; developing the ability to establish 


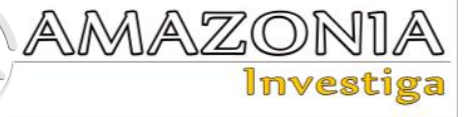

constructive relationships with others; displacing being in cyberspace from leading activities; normalization of emotional response to difficult life situations.

Thus, it can be concluded that the timely implementation of psychoprophylactic and psychocorrective measures will positively contribute to the process of overcoming cyberaddictions, as individuals who are prone to addiction will be subjected to targeted influence to prevent the emergence of relevant destructive tendencies.

\section{Conflict of interest}

The authors declared no potential conflicts of interest with respect to the research, authorship, and/or publication of this article.

\section{References}

Aymedov, C.V., Asieieva, Yu.O., \& Cherevko, M.O. (2017). Non-chemical dependencies: current trends. Medical $\begin{array}{llll}\text { psychology, } & 12, & 1(45), & 13-19\end{array}$ http://www.mps.kh.ua/archive/2017/1/3

Bartkiv, O., \& Makhnovets, V. (2018) Study of students' propensity to Internet addiction. Youth and the market, 2 (121), 141-146 http://nbuv.gov.ua/UJRN/Mir_2015_2_31

Berezhnova, D.B., \& Moskalenko, A.A. (2017) The influence of the virtual environment on the aggressive behavior of adolescents. Theoretical and practical aspects of social pedagogy and psychology of deviant behavior, 11-14 https://www.elibrary.ru/item.asp?id=30084259 Blachnio, A., Przepiorka, A., Benvenuti, M., Mazzoni, E., \& Gwendolyn, S. (2019). Relations Between Facebook Intrusion, Internet-addiction, Life Satisfaction, and Self-Esteem: a Study in Italy and the USA. International Journal of Mental Health and Addiction, 4. P. 18-38. https://www.springermedizin.de/relationsbetween-facebook-intrusion-internet-addictionlife-sat/16353444

Bolbot, T.Yu. (2005) Mental and behavioral disorders in young people with computer addiction (clinic, correction and prevention). (author's ref. dis. ... Cand. honey. Science). Ukrainian Research Institute of Social and Forensic Psychiatry and Addiction of the Ministry of Health of Ukraine. K., 36. http://www.disslib.org/psykhichni-tapovedinkovi-rozlady-v-osib-molodoho-viku-zkomp-juternoju-zalezhnistju.html

Borisova, T.S., \& Soltan, M.M. (2019) On the possibilities of using the method of medical prevention of computer addiction. Military medicine, $\quad 3, \quad 16-21$. http://rep.bsmu.by/handle/BSMU/25017

Fomenko, A.I., \& Sementsova, I.A. (2018) Prevention of cyberadication as the basis for the prevention of criminal behavior in adolescents with a borderline state of mind. Proceedings of higher educational institutions. North Caucasian region. Series: Social Sciences, 2, 113- 118 https://cyberleninka.ru/article/n/profilaktikakiberaddiktsii-kak-osnova-predotvrascheniyaprestupnogo-povedeniya-podrostkov-spogranichnym-sostoyaniem-psihiki Griffiths, M.D., Kuss, D.J., \& Billieux, J. (2019). The evolution of Internet addiction: A global perspective. Addictive Behaviors, 193-195

Ilnytska, L.A. (2012) Ways to provide psychological support to people addicted to the Internet in adolescence. Science and education: scientific-practical. magazine. south Science. center of the National Academy of Pedagogical Sciences of Ukraine, 11, 57-61. https://scienceandeducation.pdpu.edu.ua/doc/20 11/11_2011/16.pdf

Jeong, J,B., \& Lee, J.Y., Bo, M.K et. al. (2020). Associations of personality and clinical characteristics with excessive Internet and smartphone use in adolescents: A structural equation modeling approach. J. Addictive Behaviors, 11, 25-33. https://pubmed.ncbi.nlm.nih.gov/32559608/

Kemp, S. (2020). Digital 2020 Global Overview Report, for The Next Web. https://wearesocial.com/digital-2020

Khilko, O.V. (2018) A practical approach to the prevention of computer addiction in adolescents. Scientific-methodical electronic journal "Concept", 13, 56-60. https://ekoncept.ru/2015/85012.htm

Litvinova, S., \& Protsenko, T. (2006) Program of the course "Informatics" for evening (shift) secondary school 10-12 grades. "Informatics and information technology in educational institutions" 4-5 https://imzo.gov.ua/osvita/zagalno-serednyaosvita-2/navchalni-prohramy-5-9-klasynaskrizni-zmistovi-liniji/osnovy-zdorov-yanaskrizni-zmistovi-liniji/\#_ftn1

Markova, M.V. (2013) Addictive status of student youth of Kyiv: psychosocial, clinical and structural analysis. Medical psychology, 8 (3), 34-41.

http://www.mps.kh.ua/authors/105/markova_m_

Molyako, V.O. (2013) The problem of functioning of creative perception in the conditions of excess of information of different modality and significance. Actual problems of psychology: Collection of scientific works of the GS Kostyuk Institute of Psychology of the 
National Academy of Pedagogical Sciences of Ukraine. K.: Phoenix Publishing House, 12 (16), 7-19.

http://www.appsychology.org.ua/data/jrn/v12/i1 6/3.pdf

Naydionova, L.A. (2017) Cyber-bullying of adolescents (virtual terror) as the latest phenomenon of the information age: theoretical and methodological principles of overcoming and prevention. Practical Psychology and Social Work, 8, 10-18. http://mediaosvita.org.ua/pronas/najdonova-lyubov-antonivna/

Order № 664. Curriculum for secondary schools "Fundamentals of health. Ministry of Education and Science of Ukraine, Verkhovna Rada of Ukraine, 06.06.2012. Https://zakon.rada.gov.ua/rada/show/v0664736 12 \# Text

Otte, S., Streb, J., Rasche K., \& Franke, I. (2019). Self-aggression, reactive aggression, and spontaneous aggression: Mediating effects of self-esteem and psychopathology. Aggressive Behavior, 45, 31-34

Polyakova, A. (2018) Only 58\% of Ukrainians use the Internet - research. Economic Truth. https://www.epravda.com.ua/rus/news/2018/01/ 31/633590/

Resolution № 608. "On Approval of the Standard Regulations on the Center for Social and Psychological Assistance" Cabinet of Ministers of Ukraine, of May 12, 2004 https://zakon.rada.gov.ua/laws/show/608-2004$\% \mathrm{D} 0 \% \mathrm{BF} \# \mathrm{Text}$

Rumpf, H.J., Achab, S., \& Billieux, J. (2018). Including gaming disorder in the ICd-11: The need to do so from a clinical and public health perspective. J. Behav Addict, 7 (3), 556-561. doi: 10.1556/2006.7.2018.59

Rzhevsky, G.M. (2018) Analysis of personal characteristics and causes of Internet addiction in students of higher educational institutions. International scientific and practical conference $\begin{array}{llll}\text { world } & \text { science } 1 & \text { (29), 5, 50-60. }\end{array}$ https://www.elibrary.ru/item.asp?id=32314974
Sherbakova, N.B. (2018) Strategic foundations of parents' activity in organizing schoolchildren's work on a computer at home. Bulletin of the Moscow State Regional University. Series: dagogy, $3, \quad 78-88$. https://cyberleninka.ru/article/n/strategicheskieosnovy-deyatelnosti-roditeley-po-organizatsiiraboty-shkolnikov-na-kompyuterev-domashnihusloviyah

Soldatova, G.U., \& Rasskazova, E.I. (2017) The role of parents in improving the safety of the child on the Internet. Psychology issues, 2, 3-15. https://istina.msu.ru/publications/article/460516 6/

The concept of preventive education of children and youth: approved by the Presidium of the Academy of Pedagogical Sciences of Ukraine on February 25, 1998. Protocol № 1-7 / 3-21 // Teacher, 2000, № 1-3, 6-11 https://zakon.rada.gov.ua/rada/show/v124373611\#Text

Utz, S. (2015). The function of self-disclosure on social network sites: Not only intimate, but also positive and entertaining self-disclosures increase the feeling of connection. Computers in Human Behavior, 45, 1-10. doi: 10.1016 / j.chb.2014.11.076

World Health Organization-WHO. (2017). Depression.

http://www.who.int/topics/depression/en/

Young, K. S. (1996). Psychology of computer use: addictive use of the internet: a case that breaks the stereotype. Psychological reports, 79, 899-902.

Zavadsky, I.O., Potapova, Zh.V., Doroshenko, Yu.O. (2008) Informatics and information technologies in educational institutions. Curriculum in computer science for 9-12 grades of secondary schools. Standard level, http://176.102.48.88/ftp/kabinet/info Zhaojun, M., Pontesbc, Q. N., \& Guangcan, D. (2020). Internet gaming disorder and psychosocial well-being: A longitudinal study of older-aged adolescents and emerging adults. J. Addictive Behaviors, 11, 5-11. 